\title{
Effectiveness of Dzikir Therapy in Improving Religious Commitment
}

\author{
Ulfiah Ulfiah \\ Faculty of Psychology \\ UIN Sunan Gunung Djati Bandung \\ Bandung, Indonesia \\ ulfiah@uinsgd.ac.id
}

\begin{abstract}
One of the challenges of future education is the continuity of value education. In order for the noble values that become the reference in behavior, can be transformed from generation to generation, especially in order to dismiss the negative impacts of social change, continuous efforts must be made in various activities in order to increase its diverse commitments. Building a society including a moral and civilized young generation is a responsibility and a challenge, as building character requires awareness and participation of all parties. The challenge comes from within and outside the country due to an unstoppable flow of information. The phenomenon of juvenile delinquency until now is still happening like bullying, smoking and even drinking. The research was conducted on students who have problem in MTsN Bandung by using qualitative approach. This approach is done to examine the dynamics of juvenile delinquency behavior (students), factors causing juvenile delinquency and the effectiveness of dhikr therapy to handle troubled students in madrasah. At the technical level, the following steps are taken: Descriptive analysis method and collaborative participatory method. One of the services used in addressing these problem students using dhikr therapy. Proven Dhikr can control one's faith in performing religiously forbidden acts as well as drinking (khomer). Thus, the therapy of evil dzikir in increasing religious commitment to the students.
\end{abstract}

Keywords—dzikir therapy; religious commitment

\section{INTRODUCTION}

Humans are created by Allah Swt only to obey and worship Him by way of commands and keep away from all His prohibitions. But as human development begins to forget God's commands and perform deeds that are incompatible with religious norms and norms of society such as gambling, drunkenness, adultery (free sex), and even murder. This demonstrates low religious commitment.

Religion is a value system that contains the norms of life and makes the frame of reference in behaving and behaving. According to Mc. Guire a system of value-based religion can give individuals and communities the value system tools in the form of legitimacy and justification in regulating individual attitudes and societies [1].

Religion is often identified with religiosity. Although it is rooted in the same word, but in its use the term religiosity has a meaning that is different from religion or religion. Religion refers to the formal aspects related to rules and obligations, while religiosity refers to the religious aspect that has been lived by the individual in the heart [2]. Religiosity is defined as how much knowledge, how firm the belief, how the practice of worship and the rules and how deeply it is to appreciate the religion it embraces. For a Muslim, religiosity can be known from how far the knowledge, beliefs, implementation and appreciation of Islam [3].

Religious Commitment or religious commitment is one's ability to apply and internalize religious values into his life and is reflected in his attitudes and behaviors. In the term Indonesian religious commitment is often interpreted with religiosity, therefore the next author will use the term religiosity in this discussion. Religiosity includes: dimension of belief (ideological dimension), ritual dimension (dimensional ritualism), dimension of experience or appreciation (experiment dimension), dimension of knowledge (intellectual dimension), and dimension of consequence (consequential dimension) [4].

Teens are interested in religion and consider religion to play an important role in life. Interest in religion, among others, is seen by discussing religious issues, pursuing religious studies in schools and colleges and attending religious ceremonies [5]. If a teenager does not have a life guide or in this case is a religion, then in a confusing situation and inner conflict will cause adolescents to be at the crossroads. It's difficult to make the right choice. In such a situation, the opportunity to appear deviant behavior will be revealed [1]

Adolescence is the age at which an individual is integrated with an adult or transitional period in which he or she changes in mental, emotional, social and physical maturity [5].

In the course of the transition it is likely to cause a crisis, characterized by the tendency of deviant behavior. Such deviant behavior under certain conditions will be a disturbing behavior. Looking at these conditions if supported by a less conducive environment in the school environment or in the family environment due to the lack of cultivation of religious values towards adolescents it will be a trigger of various irregularities in behavior and negative acts that violate rules and norms in society which is usually referred to as juvenile delinquency. 
Delinquency of adolescents is the malicious behavior or disorder of young people, which is caused by a form of social neglect, so they develop a deviant form of behavior [6]. While juvenile delinquency according to Sudarsono is an act contrary to the norms existing in the society in which he lives or resides, or an anti-social act in which the anti-normative elements are contained [7].

The juvenile delusional paradigm is broader in scope and is more in weight. The delusions of adolescents include acts that often cause unrest in the community, school or family. The behaviors that have arisen include bullying, theft, vandalism, brawl and even brawl among students who often develop into fighting and fighting between schools. More precisely this phenomenon is not only in the public school environment, but in Madrasah which is in fact a religious school that contains many religious subjects.

Based on preliminary study at the State Tsunami School of Madrasah of Bandung and conducting interviews with a group of students who are following the counseling counseling activities in the madrasah, it can be seen that from 50 the only troubled students were 4 people who did not smoke, and only 5 people who did not drink (khommer). There are also students who escaped during break time and when followed caught smoking by using school uniforms. There are also students who often overslept when from his house brought a motor vehicle and departed early, but it turns out when traced by the school students are deliberately oversleeping and stop at the stall for coffee and smoking and even dare to drink loud. Now the phenomenon of juvenile delinquency is certainly a problem towards the achievement of the quality of education. In the school environment, it is certainly not easy to eliminate the acquaintance, given the puberty factor in adolescence, identity crisis, the formation of peers, family factors, social and others that can be one that affects his behavior. In adolescence the need for social identity is something very powerful, so they will accept only the requirements given by the group. The search process of identity is done by teenagers to get clarity to know himself and to shape himself into a whole and unique. In adolescents have a desire to no longer depend on their families and start looking for support, a sense of security from peer groups. Hence the search for their identities can be obtained through self-incorporation into peer groups or idolized groups. For teenagers, group acceptance is important because they can share their feelings and experiences with their peers and groups. Peer groups in this regard include senior students who later became models for adolescents in search of identity [8]. With the background description of the problem above, it is important to study how the profile of delinquency teen, what is the dominant factor of background and how the evolution of dhikr therapy in students.

\section{METHOD}

One of the challenges of future education is the continuity of value education. In order for the noble values that become the reference in behavior, can be transformed from generation to generation, especially in order to dismiss the negative impacts of social change, continuous efforts must be made in various activities in order to increase its diverse commitments.
Building a society including a moral and civilized young generation is a responsibility and a challenge, as building character requires awareness and participation of all parties. The challenge comes from within and outside the country due to an unstoppable flow of information. The phenomenon of juvenile delinquency up to now still rife happening like bullying, smoking and even drinking liquor one of the service used in overcoming the problem student by using dhikr therapy.

In this research, using qualitative approach. This is done to examine the dynamics of juvenile delinquency behavior (students), factors causing juvenile delinquency and the effectiveness of dhikr therapy to handle troubled students in madrasah. At the technical level, the following steps are taken: Descriptive analysis method and collaborative participatory method.

Descriptive analysis method is implemented to explain systematically, factually, accurately, about facts and traits related to research substance. In this case conducted to analyze the tendency of juvenile delinquency, factors causing juvenile delinquency and counseling efforts to address the intended mischief.

Collaborative participatory method in the feasibility test process of dhikr test Feasibility test carried out by rational test of legibility test, practicality test and limited trial. The rational test involves three guidance and counseling experts, the legacy of involving students from Madrasah Tsanawiyah. Practical testing is conducted through focused discussions involving teachers, Counseling Teacher (BK) and Head of Madrasah.

Discussion of the results of this study begins with the analysis of juvenile delinquency profile, followed by the analysis of the dominant factors causing juvenile delinquency. Then discussed the effectiveness of dhikr therapy to handle juvenile delinquency in students in MTsN Bandung.

\section{RESUlTS AND DisCUSSION}

\section{A. Analysis of Juvenile Delinquency Profile in State \\ Madrasah Tsanawiyah (MTsN) in Bandung City}

The overall profile of juvenile delinquency in Madrasah Tsanawiyah Negeri (MTsN) Bandung City is known from the results of research on rational emotive counseling behavior in handling bullying offender in madrasah following: Bullying behavior $65.98 \%$ is in rare category, $34.02 \%$ are in the category sometimes and no one is in the category often. Having known the category of bullying behavior in MTsN Bandung City also studied things related to the characteristics of bullying [9].

Characteristics of bullying actors consists of six aspects that include: lack or lack of empathy; bad interpersonal skills aspect; unskill aspect in anger management; weak aspects of self-control; less responsible aspects; and aspects of an impulsive-aggressive behavior pattern. The results of research on characteristics of bullying actors are as follows. 


\section{1) Empathy}

The results showed that the actors as a whole on the aspects of lack or lack of empathy, $62.89 \%$ were in the rare category, $36.08 \%$, were in the category occasionally and $1.03 \%$ were in the frequent category.

Indicators of the inability of the bullying bullies are: (1) not thinking about the consequences of an action; (2) glad to see others in trouble; (3) prioritizing self-interest; (4) self-effacing; (5) does not show respect to others; and (6) do not feel guilty after hurting the physical or the hearts of others.

In the context of bullying, the offender has a low empathy so he does anything without thinking too much about the consequences and the impact on others. Simply put, Borba interpret empathy as a skill to understand and feel the problems of others [10]. Blanchard states: "Empathy is something you only get by experience or by having someone model it for you" [11]. Empathy is an emotion that makes a child very sensitive to the pitiful circumstances experienced by others and move his conscience.

This inadequacy of empathy does not just happen in the perpetrator but arises and occurs because of the habituation he has received since childhood [11]. Furthermore, Coloroso provides the perspective that while the perpetrator is bullying, he or she does not lack empathy [10]. Empathy is still there, buried deep in his soul, but it takes time and effort to get it out. Thus, the effort to bring up and re-teach empathy is an obligation of all parties related to the child's life.

Marian suggests that, to cultivate empathy in children, adults can use rational emotive modification strategies. The way that can be done is to describe the situation of the victim in a way that does not blame, identify deficiencies, efforts that have been done by children and show the gap between beliefs and actions of children.

\section{2) Bad Interpersonal Skills}

The characteristic of the bullying offender is then the aspect of bad interpersonal skills. The results showed overall on the aspect of bad interpersonal skills as much as $67.01 \%$ were in the rare category, $31.36 \%$ were in the category occasionally and $1.03 \%$ were in the frequent category. This shows that in the students of MTsN Bandung there are still problematic behaviors in the form of interpersonal relationships such as disrespect others show hostility to others, happy to give orders or dominate others and associate with certain people (gangedup).

Rigby supports the research findings with the statement that, "... bullies are sometimes supposed to be hopelessly lacking in interpersonal skills" [12]. Bullying actors sometimes appear to be very lacking in terms of ownership of interpersonal skills. The word 'sometimes' indicates that not all or all of the offenders are experiencing a lack of interpersonal skills. Olweus supports this opinion by reporting on the results of his study of 30,000 Australian students. The study suggests that bullying students have more friends and tend to be more popular than students. In general, however, bullying students are less accepted by their peers, besides bullying students tend to be unmotivated by the encouragement of teachers who try to teach them interpersonal skills to be liked by their peers.
Research by Crick, Casas and $\mathrm{Ku}$ indicates a correlation between bullying behavior with poor peer relationships $(\mathrm{r}=$ $0.59)$, peer rejection $(\mathrm{r} 10=67)$, internalized problems $=0.48)$ and lack of prosocial skill $(r=0,57)$ [13]. The highest correlation is in peer rejection, which proves that bullying actors tend to lack positive interpersonal skills to others so that they are rejected by peers [14].

\section{3) Anger Management}

The results showed that overall on the unskill aspect in anger management of $70.10 \%$ was in the rare category, $28.87 \%$ was in the category occasionally and $1.03 \%$ were in the category often.

Although anger (anger) had studied in specific studies of bullying, this construct is also sometimes discussed in studies surrounding sublipe aggression [13] [15] [16]. A study by Bosworttr, Espelage and Simon of 558 high school students, anger was found to be the strongest predictor of bullying [17]. Anger also becomes a significant predictor of increased intensity of bullying behavior over the next six months. Students who are in a state of anger are mostly reported to have increased in terms of bullying actions conducted throughout the school year [13] [18].

The findings are combined with a consistent relationship between aggression and anger, indicating the importance of anger management training that is considered beneficial for some students who are bullying with their peers. Research related to bullying and anger need to be more developed in order to find anger management component which will become specific target of counseling intervention given.

From the above description, indicate that education in madrasah especially MTsN in Bandung still need effort of quality improvement, so that education is not only capable at the level of cognition but rather the integration between cognition and affection, as where Bloom's theory that, education is measured in three domains namely the cognitive, affective and psychomotor domains. Especially now our education is more programmed in character education. This becomes an urgent if more character education is developed in each subject especially in self-development activities as a developmental response of this aggression phenomenon.

\section{4) Self-control is weak}

In the weak aspect of self-control though not in the high category. However, the results show that overall on the aspect of weak self-control of $86.60 \%$ is in the rare category, $13.40 \%$ is in the category sometimes and no one is in the category often.

Self-control is the thing which is important because it can guide a person's first reaction to a particular situation [13] [19]. Associated with the results of the study, Slee conducted a study to investigate the relationship between self-control with the status of 'bully' in adolescents [13]. Subjects included 76 school-age students from 10-15 years old who were categorized as bullying and without status based on self-report and teacher-report. An illustration of the story of an imaginary child performing bullying acts against another student was read to the participants (the subject of the study), the story also stated that the action was done for no apparent reason and 
occurred over a period of weeks. Responses to questions related to the story line determine the level of participants' selfcontrol. The responses of students belonging to the bullying category show strong associations with low levels of selfcontrol.

According to Cole and Bambara strict behavior contracts can not fully control the behavior of the students unless accompanied by an adult who supervises and directs them [20]. Systemic manipulation attempts against 'behaviorol antecedents and consequences' can reduce serious problem behaviors, particularly for bullying that often escapes adult supervision [21]. The establishment of clear rules to prohibit bullying can contribute to student self-control related to bullying [13] [22].

The self-management strategy can encourage students to change or maintain their behavior and promote independence and behavioral competence in both monitored and unmonitored school settings. Other behavioral strategies such as selfmonitoring, self-evaluation and self-reinforcement can help students improve their behavioral self-control and reduce problem behaviors [20].

About self-control, Ibrahim Elfiky explains how to control oneself through feelings and behaviors by way of mind control [23]. As the power of the mind gradually diminishes, the strength of the feeling gradually diminishes.

Next, the feeling will come out following the thoughts you specify. As long as the feelings fit the mind, you can more quickly and easily respond to them. Excessive mind-thinking produces excessive feelings. If someone says, "I am sad" then this thought is in place, time, matter, and strength. These four cases are in a place called quantum. He's the one who controls human behavior.

One expert at Harvard University says, "Something you say to yourself turns into a belief .... Change your beliefs, your life will undoubtedly change." Change your mind, your life will undoubtedly change. Change your feelings and knowledge, your life will undoubtedly change. All this comes from knowledge, then transforms into a meaningful mind. After that, become concentrated, then give birth to feelings that direct behavior. And, behavior has a real impact. If you want to change your reality, change your knowledge. Because, you use the mind of energy and time [23].

Similarly, madrasah students who actually have a lot of religious material still need guidance or direction either from teachers, head of madrasah and counseling teachers so that students have a strategy effective for self-control in order to behave in accordance with the guidance of his religion, which in turn madrasah education can be an example in religious education for students.

\section{5) Less responsible}

The research results show overall on the less responsible aspects of $67.01 \%$ are in the rare category, $32.99 \%$ are in the category sometimes and no one is in the category often.

Along with the research findings, the results of Pearce's study of the subject high school students to investigate the personal characteristics of bullies indicates that bullying students exhibit low levels of the risk response index. It means that bullying students fail to identify personal obligations and consequences for violations of the obligations.

The only way to teach students to be responsible is to give them responsibility. However, to teach how to be responsible requires not only a detailed knowledge of the characteristics of a particular student but also takes time. It would be more difficult if students had to deal with groups or adults who had other commitments or priorities. Adults need to take a little time to consider individual student needs and provide supervision and attention to individual people if needed. Responsibility is taught gradually, step by step, tailored to the specific needs of each student, this is done to prevent students from failing to assume responsibility that can be dangerous. The responsibilities taught to students must be in accordance with their portion, if excessive it will lead to anxiety and even failure coping strategy.

\section{6) Impulsive-aggressive}

On the aspect of the impulsive-aggressive behavior pattern, the results showed overall on the aspect of impulsiveaggressive behavior of $81.44 \%$ in the rare category, $18.56 \%$ in the occasional category and none in the frequent category.

Pearce in Esya Anesty suggests some characteristics of bullying behavior, among which the top ones are aggressive to any person, poor impulse control, and violence seen as positive quality [14]. The statement reinforces the results of research showing that the most prominent characteristic (the greatest percentage) is an impulsive-aggressive behavior pattern, in which bullying students have impulsive behaviors that lead to aggression against others.

\section{B. Analysis of Dominant Factors Underlying juvenile delinquency in State Madrasah Tsanawiyah (MTsN) Kota Bandung}

The juvenile delinquency, as well as bullying behavior, smoking and drinking does not occur accidentally or just happen without cause, bullying behavior arises from learning prosos and is a learned thing. Therefore, bullying behavior can be reduced through a new learning process [24]. Banks suggests that bullying behavior can be identified since the child is in the pre-school age and the child who is the bullying agent at this age tends to continue his bullying behavior until adulthood [25].

Related research results can be seen that the dominant factor causing the bully is derived from the self factor the individual is the factor of religious commitment, compared with parenting factors or peer factors.

Deerwester mentions, there is a relationship between parenting style and bullying behavior, as well as the results of this study, interesting to note that, the perpetrators of bullying due to parental parenting style that constraining, so that children have empathy the poor, the bad interpersonal skills, the unskillful in anger management, weak self-control, lack of responsibility and aggressive-impulsive behavior.

Related factors causing bullies on the internal aspects above is a religious commitment. In this study shows the most dominant cause of bullying actors among these factors is 
religious commitment factor. With these findings it is known that religious guidance or religious therapy both with the therapy of Al-Qur'an and dhikr therapy still needs to be done considering religion is one part of human life that can not be separated.

Allah ordered in Q.S. al-Baqoroh verse 208, that enter into Islam in kaffah (whole). In any religion, there will be various teachings that must be practiced by its adherents in other words, what one obtains in his religious teachings should be reflected in his attitude and behavior in everyday life. This can be obtained when a person is truly committed to his religious teachings.

As Glock \& Stark puts it, "religious commitment is one's ability to define and internalize religious values in everyday life so as to reflected in the form of behavior in accordance with the teachings of religion that believed" [26].

Religion or religiosity can be realized in various sides of human life. Religious activity not only occurs when a person performs a ritual (worshiping) behavior, but also when a human does another activity that is driven by supernatural powers. Not only is it related to activity that is visible and visible to the eye, but also activity that does not appear and occurs in one's heart, therefore one's religiousness will encompass various sides or dimensions.

According to Glock \& Stark there are five dimensions contained in religious commitment. These five dimensions are not entirely independent of each other, but rather occur moderately to each other [26]. Thus a person who has a strong belief, should have a habit of carrying out diligent rituals and have more sensitive religious feelings as well. The five dimensions are: Dimension of knowledge, dimension of belief, dimension of religious practice, dimension of experience and dimension of consequence.

\section{Analysis of the Effectiveness of Dhikr Therapy on Students \\ Therapy Dzikir}

The word "therapy" (in English) means treatment and healing, whereas in Arabic the word therapy commensurate with (al-Istisyfa) which means to heal. As has been used by Mohammed Abdul Aziz al Khalidiy in his book "Al Istisyfa 'Qur'an bil).

In Surat al-Isra verse 82 which means: "And We sent down from the Qur'an something (which can be) a healer and a mercy to those who believe (believe and believe), and the Qur'an will not add to those who do wrong but to loss "(QS Al-Isra ',: 82). While in Surah As-Sajadah verse 44 it says: "Say: The Qur'an is for those who have believed is a guide and a healer" (QS As Sajadah ,: 44).

As for dhikr in terms of meaning is a way to remember Allah in taqarrub's effort to Him. Thereby Dzikir Therapy is a healing effort with dhikr both dhikr with oral and other worship. But before it is necessary to note that dhikr with oral is partially a prayer. Thus, when one prays, he is actually dhikr

\section{1) Types of Dhikr}

Based on practice, dhikr is divided into three parts, namely: a. Dzikr bil 'Amal, that is all the acts whose purpose is to remember Allah SWT. for example, a student never cheats on a test, because he knows that God is always watching every moment and opportunity.

b. Dzikir Aqliyah, that is dzikir of knowledgeable people (ulil albab) by way of tafakur and tadabur. They use the knowledge they have to dhikr to God. This is important because when scientists do not use their knowledge to dhikr to God, their knowledge tends to make them arrogant.

c. Dzikir oral bil, that is every pronounced utterance with the purpose to remember God. For example, say istighfar, takbir, tahmid, and tahlil after completion of fardhu.d prayer.

d. Qilbi's dhikr dhikr, which is the heart that always remembers Allah when the path appears to do immoral. For example, when we intend to take the goods of others, but do not do so for fear of the punishment of Allah SWT. [27].

Dhikr bil 'Amal and Dzikir bil Qalbi is also called Dhikr' Aam (general) because it involves all the deeds done by all limbs, including the heart.

Dzikir bil Lisan, also called Dzikir Khaash (special) because it only relates to the sentence of dhikr which is pronounced like reading Subkhanallah, Walkhamdulillah, Walaailaahaillah, wallaahuakbar. Dzikir Lisan bil has two ways in practice, namely: sir (dhikr with the sound slowly so that only heard by himself) and Jahar (dhikr with a loud voice so heard by the ears of those around him). Sheikh Ibn Qayyim Al-Jawziyyah divide the dhikr in two parts, namely:

a. Dhikr of Asthma and His nature Be awakened always by dhikr, that is dhikr of asthma and His nature. His Asma (His names) consists of 99 names, commonly known as Asmaul Husna. Always call his asthma with an unlimited heart or verbal count at every possible opportunity. To dwell with His attributes, that is by carrying out His commandments

b. Dzikir on His command and prohibition and His laws Dhikr on command and prohibition and its laws certainly not in the sense of mentioning it with oral words and pass it in the heart as well as on asthma dhikr and his nature, but remembering - always remember what the obligations should be done on the basis of His command and what should be abandoned on the basis of his prohibition [27].

2) The virtue of Dhikr.

Got Peace of Allah's Heart Swt. says, "(Ie) those who believe and their hearts are rested in the remembrance of Allah. Remember, it is only in the remembrance of Allah that the heart is rested. "(Q.S. Ar-Ra'd [13]: 28);

a. Always Remembered by Him Allah says, "Therefore, remember ye to Me I will remember you, and give thanks unto $\mathrm{Me}$, and do not disobey Me." (Q.S.AlBaqarah [2]: 152) 
b. Receive Allah's Refuge on the Day of Resurrection Rashulullah said, "There are seven groups that will be protected by God in the day of no-god's protection on the day of no protection, Someone who dhikr to Allah by aloof tears in his eyes. (H.R. Bukhari).

c. Can unleash the demon binders when waking up Rasulullah Saw. said, "Satan tied a man's head when he slept with three ties made all night long. So go to sleep, and if you wake up then remember (dhikr) to Allah, loose a bond, then if he perform ablution, the second bond will be released. Then if you continue with the prayer, release the third bond. So be in the morning in a state of intelligence, clean his soul, and if not do it, he wakes up in the morning in a dirty and lazy spirit ". (H.R. Bukhari)

d. Makes Life alive Rasulullah Saw. said, "The parable of the one who remembers his Lord with the one who does not (remember his money), is like living with the dead." (H.R. Bukhari).

e. Can soften the heart of Rasulullah Saw. said, "Do not you multiply talk except dhikr to Allah, because in fact many talk without dhikr to Allah will harden the heart, and so far man from God is the heart hard". (H.R. Tirmidhi)

\section{3) Benefits of Therapy Dzikir}

Terapi dzikir can be done on individuals who are experiencing mental (mental), such as reciting the verses of Allah, the purification and teaching of the Qur'an and Alhikmah. Therapeutic dhikr can make mental healthy individual, namely 'exposed the perfection of the soul, exposed uluhiyah intelligence, rububiyah intelligence, ubudiyah intelligence and intelligence khuluqiyah.Tujuan test the effectiveness of dhikr therapy service for students problem in MTsN Bandung consists of analysis of the implementation of intervention. The effectiveness test result through counseling analysis analysis shows that, counseling program is quite reliable. This can be proved by positive feedback and impressions from group members on the whole counseling session. In the intervention given to the students of Class IX MTsN Bandung, the materials and activities undertaken focused on helping group members learn various skills, one of which is developing interpersonal skills. The dhikr therapy group directly instructs its members to improve their personal and interpersonal skills so that problems can be reduced. Thus, the selection of dhikr therapy to increase religious commitment in students MTsN Bandung can be said in accordance with the needs of members of the group (konseli). Sesi intervention in therapy dzikir relatively focused and shorter is considered very effective for adolescents. The dhikr therapy holds a meeting session twice a week for 45 minutes each session. Eight intervention sessions with duration for 45-60 minutes is considered sufficient. Short-term dhikr therapy is considered to be more symptomatic than other counseling approaches. However, for the sake of successful counseling, counselor karakreristik, intervention conditions, levels of experience and expected results remain a matter to consider. The form of reinforcement done in dhikr therapy for students, is not a reinforcement that affirms the behavior of the problem itself, but the strengthening leads to the desire and commitment to change negative behavior into new behavior more effective, so that students are given strong motivation related to the implementation of dhikr at every time, and at least after praying dhikr must be done. Dzikir therapy approach has advantages compared to counseling using another approach. Dzikir therapy is a didactic approach. Counselors are educators who need to transfer knowledge and skills about dzikir to the counselee. This characteristic is consistent with the guidance and counseling in Indonesia which is in the area of education in general, as well as guidance and counseling activities in particular should bring individuals to follow the way of life (Islam) in accordance with God's command professionally. In fact, Indonesian education that places teachers (including counselor teachers) in a position that can not be simultaneously equivalent to students (some counseling approaches putting counselors and counselors in an equal position) can be of value to dhikr therapy. Another advantage is the approach of dhikr therapy aims to counselee eventually become a therapist for himself. It is the reason the counselor teaches the knowledge and skills about dhikr to the counselee. The purpose of this dhikr therapy is in line with the dream counseling that wants the counseling process to establish students. Another advantage is dhikr therapy can also be done individually and more effectively if done as a group. Based on the description that has been described above then, can be put forward some advantages of dhikr therapy in the school/madrasah setting as follows. 1. The purpose of dhikr suits the purpose of counseling and counseling to establish students. This is evident in the step in counseling when counseling is stopped when the counselee can understand and practice dhikr in problem solving. 2. The role of dhikr therapy counselor as an educator has the same context with counselor in Indonesia who is a teacher of guidance and counseling. This commonality places the Master Teacher in a school / madrasah in Indonesia as an educator who carries the mission of religious values on student life. 3. The number of counseling sessions can be shortened by combining face-to-face meetings and consultation sessions using on line counseling. 4. Another way that counselors can use in facilitating dhikr therapy is to make media used in counseling, such as guidebooks on dhikr therapy and other materials as supplements in counseling activities.

\section{CONCLUSION}

Peace and tranquility is the desire of every human being. Therefore, in the grateful of the favors of God we do not do the satisfaction for itself, but it takes consideration and self-control in behaving in accordance with religious values so that behavior is not behavior that is prohibited by religion.

The world is where we live, and we need it. But he is not everything. It takes a balance for the achievement of the ideals of a happy life, the world and the hereafter, and especially so that we have a high emotional stability and are not susceptible to stress, depression and frustration, thus possessing a soul muthmainnah ie; soul that always invites back the divine nature of God. The work ethic and the performance of the mind, Qalbu, the senses and the physical are always in the qudrat and the iradat of God. The Holy and the Great. 
To achieve it all, in accordance with the command of Allah, do dzikir with truth, dhikr able to get closer to God, so as to achieve optimal mental health.

\section{REFERENCES}

[1] Rahmat, Jalaludin. 2009. Psikologi Agama. Raja Grafindo Persada. Yogyakarta.

[2] Mangunwijaya. 1986. Menumbuhkan Sikap Religiusitas Anak. Jakarta : Gramedia

[3] Nashori, Fuad 2002. Mengembagkan Kreativitas dalam Perspektif Psikologi Islam. Yogyakarta: Menara Kudus.

[4] Ancok, J \& Nashori S, Fuat. 2005. Psikologi Islami. Yogyakarta : Pustaka Pelajar.

[5] Hurlock. Elizabeth B. 1980. Psikologi perkembangan suatu pendekatan sepanjang rentang kehidupan. Edisi Ke-Lima. Alih Bahasa Istiwidayanti dan Soedjarwo. Jakarta : Erlangga.

[6] Kartono, Kartini. 2011. Patologi Sosial 2 Kenakalan Remaja cetakan ke10. Jakarta : PT. Raja Grapindo Persada.

[7] Sudarsono. 2004. Etika Islam tentang Kenakalan remaja cetakan ke-4. Jakarta : Rineka Cipta.

[8] Djuwita, R. (2006). "Kekerasan Tersembunyi di Sekolah": Aspek-aspek Psikososial dari Bullying, tersedia di http//www.dltb.or.id/ index.php. (29 April 2006)

[9] Ulfiah, Konseling Rasional Emotif Perilaku Untuk menangani Pelaku Bullying di Madrasah, Disertasi, Bandung 2012

[10] Coloroso, Barbara. "The bully, the bullied and the bystander." (2003).

[11] Blanchard J. Anti-bullying program aims to teach students empathy. Seattle Post-Intelligencer. 2007.

[12] Rigby K. New perspectives on bullying. Jessica Kingsley Publishers; 2002 Jan 31.

[13] Espelage DL, Swearer SM. Introduction: A social-ecological framework of bullying among youth. InBullying in American schools 2004 Feb 4 (pp. 23-34). routledge.

[14] Anesty E. Konseling kelompok behavioral untuk mereduksi perilaku bullying siswa sekolah menengah atas: penelitian eksperimen kuasi terhadap siswa kelas XI SMA Negri 10 Bandung. Fakultas Psikologi Pendidikan dan bimbingan UPI, Bandung. 2009.

[15] Dodge KA. The structure and function of reactive and proactive aggression. InEarlscourt Symposium on Childhood Aggression, Jun, 1988, Toronto, ON, Canada 1991. Lawrence Erlbaum Associates, Inc.

[16] Price JM, Dodge KA. Reactive and proactive aggression in childhood: Relations to peer status and social context dimensions. Journal of Abnormal Child Psychology. 1989 Aug 1;17(4):455-71.

[17] Bosworth K, Espelage DL, Simon TR. Factors associated with bullying behavior in middle school students. The journal of early adolescence. 1999 Aug;19(3):341-62.

[18] Espelage DL, Bosworth K, Simon TR. Short-term stability and prospective correlates of bullying in middle-school students: An examination of potential demographic, psychosocial, and environmental influences. Violence and Victims. 2001 Aug 1;16(4):411.

[19] Jackson Y, Frick P, Dravage-Bush J. Perceptions of control in children with externalizing and mixed behavior disorders. Child Psychiatry and Human Development. 2000 Sep 1;31(1):43-58

[20] Cole CL, Bambara LM. Issues surrounding the use of self-management interventions in the schools. School Psychology Review. 1992.

[21] Walker HM. Antisocial behavior in school: Strategies and best practices Brooks/Cole Publishing Co., 511 Forest Lodge Rd., Pacific Grove, CA 93950-9968.; 1995

[22] Olweus, Dan. "Bully/victim problems among schoolchildren: Long-term consequences and an effective intervention program." (1993)

[23] Elfiky, Ibrahim. (2010). Dahsyatnya Berperasaan Positif, Rahasia Mengelola Kekuatan Perasaan Untuk Meningkatkan Ketenangan dan Kesuksesan. Jakarta: Zaman.

[24] Drosopoulos JD, Heald AZ, McCue MJ. Minimizing Bullying Behavior of Middle School Students through Behavioral Intervention and Instruction. Online Submission. 2008 May 5.

[25] Banks, Ron. "Bullying in Schools. ERIC Digest." (1997).

[26] Glock, Charles, Y. and Rodney Stark. Religion and Society in Tension. Chicago: Rand McNally and Company. 1965.

[27] Aam Amiruddin \& M. Arifin Ilham, Dzikir Orang-Orang Sukses, Khazanah Intelektual, Bandung, 2008. 